\title{
IMPLEMENTASI PEMAHAMAN LINTAS BUDAYA DALAM PEMBELAJARAN BAHASA JEPANG DI KELAS XI BB 1 SMA NEGERI 4 SINGARAJA
}

\author{
N. P. S. M. Ani ${ }^{1}$, N. N. Suartini ${ }^{2}$, I. W. Sadyana ${ }^{3}$ \\ ${ }^{123}$ Jurusan Pendidikan Bahasa Jepang, Universitas Pendidikan Ganesha, Singaraja \\ e-mail: sri.merry.ani@undiksha.ac.id, nnsuartini@undiksha.ac.id, wayan.sadyana@undiksha.ac.id.
}

\begin{abstract}
Abstrak
Penelitian ini bertujuan untuk mendeskripsikan metode yang digunakan guru dalam mengimplemetasikan pemahaman lintas budaya dalam pembelajaran bahasa Jepang di SMA kelas XI BB 1 Negeri 4 Singaraja dan kendala-kendala yang dihadapi guru serta cara mengatasi kendala tersebut. Subjek penelitian ini adalah guru bahasa Jepang di SMA Negeri 4 Singajara dan siswa kelas XI BB 1. Objek penelitian ini adalah buku teks Nihongo Kirakira II dan metode yang digunakan untuk mengimplementasikan pemahaman lintas budaya. Pengumpulan data melalui observasi, wawancara semi terstruktur dan dokumentasi berupa silabus, RPP dan foto. Hasil penelitian menunjukan bahwa (1) metode pembelajaran yang digunakan guru untuk mengimplementasikan pemahaman lintas budaya dalam pembelajaran bahasa Jepang adalah commenting, comparing, intuitivism dan case study (2) dalam mengimplementasikan metode comparing dan commenting kendala yang dihadapi guru terkait istilah-istilah budaya serta informasi yang sedang dibahas. Tetapi kendala tersebut dapat diatasi guru dengan cara mencari sumber-sumber materi budaya lainnya. (2) dalam mengimplementasikan metode intuitivism, kendala yang dihadapi terkait keterbatasan media berupa gambar ilustrasi, video pembelajaran budaya dan alat peraga untuk praktek budaya seperti yukata. Tetapi kendala tersebut dapat diatasi guru dengan cara mencari gambar dan video dari sumber budaya lain dan untuk keterbatasan yukata, guru membentuk kelompok sehingga media dapat dimanfaatkan oleh semua siswa.
\end{abstract}

Kata kunci: implmentasi, pembelajaran bahasa Jepang, budaya

\section{要旨}

本研究の目的は、シンガラジャ第四国立高校の文化言語クラスの 2 年生の日本語学習にお いて、1）教師が異文化理解の実施する為に使用された方法、2）日本語学習の障害、解決 する方法を分別する。調査協力者は、シンガラジャ第四国立高校の文化言語クラスの 2 年 生の日本語教師及び「日本語キラキラII」教科書である。調査方法は、観察、インタビュー 及び、文献調查である。分析した結果、1) 教師が異文化理解の実施の為に

使用された方法は、コメント、比較、直観主義、事例研究である。2）教師がコメント、比 較の方法を＼cjkstart実施する為の障害は＼cjkstart議論されている情報及び

文化用語に関することである。しかし、その障害は 他の

文化資料を調べることによって解決される。2）直観主義実施する為の障害は 絵カードや

文化授業のビデオや ゆかたなど使用したメディアは

少ないである。しかし、その障害は教師が他のサイトに絵やビデオを探したり、学生にグ

ループを 形成する形での クラス管理したりすることで 解決した。

キーワード：実施、日本語学習、文化

\section{Pendahuluan}

Mempelajari bahasa asing sangat penting untuk menambah informasi dan pengetahuan baik di dalam negeri ataupun di luar negeri. Dengan menguasai bahasa asing manusia akan mampu bersaing dalam menggunakan teknologi, berinovasi dan dapat bertahan menghadapi tantangan di Abad ke-21. Salah satu bahasa asing yang penting untuk dipelajari adalah bahasa Jepang.

Pembelajaran bahasa Jepang banyak diminati di Indonesia. Pendidikan bahasa Jepang di 
Indonesia, diselenggarakan pada sekolah menengah, perguruan tinggi (PT), dan pada kursus-kursus (Danasasmita, 2014). Sejak tahun 2008 Indonesia mengirimkan tenaga perawat sebanyak 792 orang. Adanya permintaan dari pihak Jepang akan tenaga perawat pada akhirnya dapat membuka peluang untuk menjadi instruktur bahasa Jepang bagi para calon tenaga kerja tersebut (Danasasmita, 2014).

Saat ini pembelajaran bahasa Jepang di pendidikan formal seperti SMA/SMK mulai menurun. Hal ini dibuktikan dengan beberapa sekolah yang hanya menjadikan bahasa Jepang sebagai mata pelajaran lintas minat. Tetapi dengan adanya peningkatan tenaga kerja yang dibutuhkan Jepang kepada Indonesia membuat minat akan bahasa Jepang dalam dunia pekerjaan lebih meningkat. Hal ini menyebabkan bahasa Jepang semakin banyak dipelajari.

Dalam mempelajari bahasa asing khususnya bahasa Jepang, siswa tidak hanya mempelajari bahasa tetapi juga mempelajari budaya. Budaya adalah suatu keseluruhan kompleks yang meliputi pengetahuan, kepercayaan, kesenian, moral, keilmuan, hukum, adat istiadat, dan kemampuan lain, serta kebiasaan yang didapat oleh manusia sebagai anggota masyarakat (Tylor 2017).

Keterkaitan bahasa dan budaya adalah hal yang penting untuk mempelajari bahasa asing. Pemahaman terhadap budaya dari bahasa yang dipelajari berperan penting dalam menentukan keberhasilan penyampaian pesan serta terjadinya komunikasi yang lancar antara penutur dan lawan bicara. Hal ini membuktikan bahwa bahasa tidak hanya bersifat struktural tetapi juga komunikatif dan sosial.

Pembelajaran budaya di dalam pembelajaran bahasa Jepang sangat diperlukan untuk menunjang pemahaman siswa terhadap materi yang sedang dipelajari. Selain itu melalui pembelajaran yang menyisipkan unsur budaya di dalam kelas membuat pembelajaran lebih dan menarik. Siswa tidak monoton mempelajari teori, sehingga rasa bosan ditengah pembelajaran dapat diminimalkan. Hal ini membuat siswa juga lebih termotivasi untuk belajar. Saat ini pemahaman lintas budaya sudah banyak diterapkan di dalam pembelajaran bahasa Jepang di Indonesia. Dalam pembelajaran bahasa Jepang, materi terkait budaya terdapat di dalam buku teks. Salah satu buku teks yang memuat pemahaman lintas budaya adalah buku Nihongo Kirakira.

Nihongo Kirakira adalah buku teks yang telah disesuaikan dengan kurikulum yang berlaku yaitu kurikulum 2013. Buku teks ini telah disesuai dengan pendekatan saintifik yang alur pembelajarannya bertujuan untuk memperhatikan kompetensi sikap, pengetahuan, keterampilan serta kemampuan untuk mampu menghadapi persaingan globalisasi pada abad 21. Pada buku teks Nihongo Kirakira terdapat 12 bab yang disetiap bab terdapat pemaparan budaya Jepang dalam kehidupan sehari-hari. Selain budaya Jepang terdapat juga budaya Indonesia agar siswa mampu membedakan kedua budaya tersebut.

Buku teks Nihongo Kirakira telah digunakan oleh banyak sekolah untuk menunjang pemahaman siswa dalam pembelajaran bahasa Jepang. Penelitian ini memfokuskan kepada buku teks Nihongo Kirakira II karena materi budaya yang dijelaskan berkaitan dengan kehidupan kemasyarakatan. Siswa akan mudah memahami materi budaya pada buku teks Nihongo Kirakira II karena terjadi dalam kehidupan sehari-hari dan dialami sendiri oleh siswa. Salah satu sekolah yang menggunakan buku teks Nihongo Kirakira adalah SMA Negeri 4 Singaraja. SMA Negeri 4 Singaraja merupakan sekolah yang aktif pada banyak kegiatan lomba berbahasa Jepang baik yang diselenggarakan oleh UNDIKSHA ataupun universitas lain. SMA Negeri 4 Singaraja sering memperoleh juara diberbagai bidang yang berhubungan dengan bahasa Jepang. Dalam sekolah ini pelajaran bahasa Jepang ditetapkan sebagai mata pelajaran lintas minat di kelas IPS dan BB (Bahasa dan Budaya).

Berdasarkan hasil observasi dan wawancara awal yang dilakukan pada hari Kamis, 16 Mei 2019 di SMA Negeri 4 Singaraja, implementasi pemahaman lintas budaya di kelas XI Bahasa dilakukan sesuai dengan buku teks Nihongo Kirakira. Guru menggunakan beberapa metode pembelajaran yang dikombinasikan agar siswa tidak merasa bosan dengan cara belajar yang monoton. Pemahaman budaya selalu diselipkan agar siswa dapat langsung memahami budaya Jepang yang berkaitan dengan materi yang sedang dijelaskan. Guru menjelaskan pemahaman lintas budaya dalam pembelajaran bahasa Jepang sangat penting dilakukan karena dapat membuat siswa lebih percaya diri dalam menggunakan bahasa Jepang. Selain memahami teori, siswa juga memahami budaya Jepang secara lebih 


\section{mendalam.}

Salah satu pemahaman budaya yang diterapkan guru adalah pada aisatsu. Guru menyapa siswa "Om Swastiastu" dengan mencakupkan kedua tangan didada dan aisatsu sambil ojigi (membungkukan badan). Salam ini juga diikuti oleh semua siswa. Kedua salam ini digunakan guru agar siswa langsung dapat mempraktekan kedua budaya yang berbeda. Guru menjelaskan bahwa ojigi adalah hal sederhana yang dapat dilakukan ketika bertemu dengan orang Jepang. Ojigi adalah sifat membungkuk yang dilakukan pada saat bertemu pertama kali atau bertemu seseorang yang dihormati

Penelitian sejenis pernah dilakukan oleh Elmes (2013) tentang hubungan antara bahasa dan budaya serta pentingnya budaya dalam mengimplementasikan pembelajaran bahasa. Saat mempelajari bahasa asing, pemahaman budaya hanya dimengerti melalui buku teks. Maka dari itu hubungan antara bahasa dan budaya perlu untuk dipahami oleh guru. Hubungan antara bahasa dan budaya dapat membantu pemahaman siswa untuk mempelajari bahasa target. Penelitian ini hanya berfokus pada implementasi pembelajaran bahasa dan budaya dalam pembelajaran bahasa Jepang dan tidak membahas tentang cara mengatasi kendala-kendala yang dihadapi oleh guru. Berdasarkan uraian di atas maka penelitian yang dilakukan berfokus pada metode pembelajaran yang digunakan dalam mengimlementasikan pemahaman lintas budaya pada pembelajaran bahasa Jepang dan kendala-kendala yang dihadapi guru serta cara mengatasi kendala-kendala tersebut.

\section{Metode}

Penelitian ilmiah menggunakan suatu langkah-langkah pelaksanaan yang dilakukan melalui rancangan penelitian. Langkah-langkah yang dilakukan secara sistematis untuk mendapatkan pengetahuan ilmiah dalam pembahasan ini terdiri dari 4 sub bab. (1) Pendekatan dan Jenis Penelitian. (2). Lokasi Penelitian (3) Jenis dan Sumber Penelitian. (4) Metode dan Teknik Analisis Data.

\section{Hasil dan Pembahasan}

\section{Data Hasil Observasi}

Pada observasi pertama, guru memperkenalkan tentang letak geografis Jepang. Letak geografis ini menyebabkan terjadinya empat musim dan perbedaan iklim yang dialami Jepang dengan Indonesia. Di Indonesia hanya memiliki dua musim, musim hujan dan kemarau sedangkan Jepang memiliki empat musim yaitu "Fuyu" (冬), musim semi “Haru” (春) , musim panas “Natsu”（夏） dan musim gugur “Aki”（秋）. Perbedaan musim ini menyebabkan berbagai kebiasaan menarik yang dimiliki oleh Jepang. Misalnya penggunaan pakaian tradisional Jepang yaitu Kimono dan Yukata.

Guru menjelaskan bahwa kimono dan yukata terlihat sama tetapi sebenarnya berbeda. Kimono biasanya digunakan pada semua musim dingin karena berbahan lebih tebal dari yukata. Kimono juga hanya dipakai pada acara resmi seperti upacara minum teh, pesta pernikahan dan acara formal lainya. Sedangkan yukata hanya digunakan pada musim panas, yukata tidak memiliki lapisan kain di dalamnya sehingga jika dipakai di musim dingin akan terasa sangat dingin. Biasanya yukata digunakan untuk suasana yang lebih santai seperti pada saat menari di perayaan obon dan melihat pesta kembang api. Sedangkan untuk pakaian tradisional Indonesia umumnya berbahan tipis karena iklimnya yang tropis sehingga dapat digunakan sepanjang tahun. Setelah selesai menjelaskan materi budaya, guru menyampaikan kepada siswa bahwa pada pertemuan selanjutnya akan diadakan praktek memakai yukata.

Pada observasi kedua, guru dan siswa akan praktek menggunakan yukata, tetapi sebelum kegiatan dilakukan guru melanjutkan materi sebelumnya. Praktek diadakan diakhir pelajaran. Praktek dilakukan di dalam kelas, siswa merapikan bangku dan kursi agar kegiatan dapat dilaksanakan dengan lebih leluasa. Karena keterbatasan yukata yang dimiliki, guru membagi siswa menjadi 10 kelompok terdiri dari 3-4 siswa. Sepanjang pelaksanaan praktek terdapat banyak kesalahan yang dialami siswa tetapi mereka tidak mudah menyerah dan sangat bersemangat. Kesalahan yang dilakukan siswa diatasi guru dengan cara menjelaskan kembali dengan lebih mendetail.

Pada observasi ketiga materi budaya yang dijelaskan yaitu tentang pekerjaan rumah Jurnal Pendidikan Bahasa Jepang | 56 
tangga yang dilakukan oleh orang Jepang. Guru menjelaskan bahwa di Jepang sangat jarang keluarga memakai jasa asisten rumah tangga, karena harganya yang cukup mahal. Seorang asisten rumah tangga di Jepang biasanya dibayar perjam dengan biaya yang tidak murah. Oleh sebab itu pekerjaan rumah tangga lebih banyak dikerjakan oleh ibu. Kebanyakan wanita Jepang setelah menikah biasanya menjadi ibu rumah tangga. Sehingga semua pekerjaan rumah ibu yang mengerjakan. Tetapi jika sebuah keluarga sudah memiliki anak, anak pun akan dibiasakan mengerjakan pekerjaan rumah sejak dini. Anak diberikan tanggung jawab agar dapat hidup mandiri dikemudian hari. Sedangkan di Indonesia keluarga yang berada dalam ekonomi yang mampu biasanya menggunakan jasa asisten rumah tangga, karena harganya yang relatif terjangkau dan digaji perbulan.

Pada observasi keempat guru menjelaskan kembali tentang budaya Jepang berkaitan dengan budaya kebersihan. Masyarakat Jepang dikenal sangat memperhatikan kebersihan rumah terutama tentang pembuangan sampah di dalam rumah. Setiap rumah tangga di Jepang tidak bisa secara sembarangan memasukan semua jenis sampah ke tempatnya. Sampah harus dipisahkan menurut jenisnya. Setelah itu dibuang pada tempat sampah yang sudah disediakan. Di Indonesia sampah hanya dibedakan menjadi dua jenis yaitu organik dan anorganik tetapi di Jepang dibedakan menjadi lebih dari dua jenis sampah. Diantaranya sampah dapat terbakar, sampah tidak dapat dibakar, sampah berukuran besar dan sampah botol/kaleng. Selain itu terdapat pula peraturan-peraturan yang harus dipatuhi seperti kantong sampah dibedakan menjadi beberapa warna sesuai dengan daerahnya. Pengambilan sampah diatur sesuai dengan wilayahnya, biasanya terdapat panduan yang menunjukan jadwal hari pengumpulan sampah.

Pada observasi kelima, guru menjelaskan mengenai rumah tradisional Jepang. Rumah tradisional Jepang terdiri dari bahan utama kayu, hal ini bertujuan untuk mengantisipasi bencana gempa serta temperatur yang berubah disetiap musim. Sedangkan rumah tradisional Indonesia dibangun dengan bahan dasar yang berbeda-beda sesuai dengan wilayahnya tetapi umumnya menggunakan batu batako agar bangunan lebih kuat dan kokoh. Guru juga menjelaskan beberapa bagian yang terdapat pada rumah tradisional Jepang diantaranya seperti Tatami, Genkan, Fusuma, dan Kamidana. Pertama, tatami adalah sebuah ayaman jerami yang biasa digunakan untuk menutupi lantai. Tatami mempunyai daya tarik terhadap rumah-rumah tradisional Jepang yang membantu ruangan terasa lebih hangat jika sedang musim dingin. Kedua, Genkan merupakan sebuah koridor yang digunakan penghuni rumah serta tamu untuk melepas alas kaki agar tidak mengotori tatami. Ketiga, fusuma merupakan pintu geser yang terbuat dari triplek atau kayu yang dilengkapi dengan kertas khusus. Biasanya kertas dalam fusuma dilukis dan diwarnai agar terlihat indah. Keempat, shouji adakah pintu dan jendala khas Jepang yang dibuat dari kertas washi yang kuat. Kelima, kamidana adalah rak dewa yang biasanya ditemukan dirumah Jepang kuno. Pemilik rumah akan menyalakan osenko atau lilin, meletakan bunga kemudian pemilik rumah akan berdoa.

\section{Data Hasil Wawancara}

Wawancara terhadap guru bahasa Jepang dilakukan sebanyak 5 kali di ruang guru SMA Negeri 1 Negeri 4 Singaraja. Wawancara yang dilakukan dengan menggunakan pedoman wawancara yang yang berkaitan dengan pemahaman lintas budaya, media pendukung pemahaman lintas budaya serta faktor-faktor yang mempengaruhi terlaksanannya pemahaman lintas budaya dalam pembelajaran.

Dalam penyampaian materi guru selalu menyelipkan pemahaman lintas budaya. Langkah awal yang dilakukan guru adalah melakukan pengamatan pada buku Nihongo Kirakira dibagian budaya. Jika terdapat hal yang tidak dimengerti, guru akan mempersilahkan siswa untuk bertanya. Setelah paham, guru akan meminta siswa untuk menjelaskan apa yang telah didapatkan dari hasil pengamatan. Apabila terdapat hal yang kurang tepat, guru akan memperbaiki penjelasan siswa. Kemudian jika sudah tepat, guru akan menambahkan materi budaya yang sedang dibahas pada bab tersebut.

Guru menjelaskan bahwa terdapat kendala-kendala yang dihadapi selama mengajar tentang pemahaman lintas budaya salah satunya kurangnya media pembelajaran. Seperti pada praktek memakai yukata, sekolah hanya memiliki beberapa yukata.Selain itu pengetahuan tentang memakai yukata masih kurang. Kendala ini diatasi guru dengan cara 
banyak bertukar informasi dengan mahasiswa yang sedang PPL di SMA Negeri 4 Singaraja. Selain itu jika di sekolah sedang ada pengajar dari Jepang, guru juga banyak bertanya dengannya. Kemudian untuk yukata biasanya guru juga meminjam kepada mahasiswa PPL. Guru mempunyai kendala lain yang berkaitan dengan kurangnya informasi tentang budaya, oleh sebab itu guru menggunakan buku-buku penunjang lain seperti Minna No Nihongo, Yasashii Nihongo No Kaiwa, Sakura, beberapa majalah Jepang dan internet.

Dalam penyampaian materi guru selalu menyelipkan pemahaman lintas budaya. Langkah awal yang dilakukan guru adalah melakukan pengamatan pada buku Nihongo Kirakira dibagian budaya. Jika terdapat hal yang tidak dimengerti, guru akan mempersilahkan siswa untuk bertanya. Setelah paham, guru akan meminta siswa untuk menjelaskan apa yang telah didapatkan dari hasil pengamatan. Apabila terdapat hal yang kurang tepat, guru akan memperbaiki penjelasan siswa. Kemudian jika sudah tepat, guru akan menambahkan materi budaya yang sedang dibahas pada bab tersebut. Apabila memungkinkan guru akan mengajak siswa untuk praktek, contohnya pada buku teks Nihongo Kirakira II bab 16 materi budaya yang dipelajari adalah "Bunyi Hewan", guru mengajak siswa untuk menirukan suara hewan dalam bahasa Jepang kemudian dibedakan dengan suara hewan dengan bahasa Indonesia.

Selanjutnya pada bab 18 materi budaya yang dipelajari yaitu “あさごはんをたべます” guru melakukan 3 perbandingan budaya dengan cara menjelaskan makan pagi di Jepang menggunakan nasi sebagai makanan pokok dan sumpit sebagai alat untuk makan. Sedangkan makan pagi di Eropa menggunakan roti sebagai makanan pokok dan sendok serta garpu sebagai alat untuk makan. Kemudian makan pagi di Indonesia mempunyai kesamaan dengan Jepang yaitu menggunakan nasi sebagai makanan pokok. Sedangkan alat untuk makan, orang Indonesia menggunakan sendok dan garpu atau menggunakan tangan.

Contoh lainnya pada buku Nihongo Kirakira II bab 14 materi budaya yang dipelajari adalah “よくそうじをします”. Pada materi ini sebenarnya menjelaskan tentang pekerjaan rumah, tetapi guru menambahkan informasi mengenai pengolahan sampah di Jepang. Guru mampu menghubungkan budaya dengan hal-hal yang ada disekitar siswa sekaligus memberikan pemahaman tentang pentingnya kebersihan lingkungan khususnya masalah sampah. Guru mengharapkan siswa dapat mengaplikasikannya di dunia nyata.

Kendala lainnya yang guru sampaikan adalah terkait praktek budaya. Guru menjelaskan bahwa tidak semua budaya dapat dipraktekan menjadi sebuah kegiatan sehingga untuk mengatasi hal tersebut guru lebih banyak menjelaskan budaya secara lebih mendalam. Guru menghubungkan pemahaman lintas budaya dengan kehidupan sehari-hari siswa, agar dapat diaplikasikan dalam dunia nyata.

Guru menjelaskan bahwa tujuan yang ingin dicapai dalam pembelajaran pemahaman lintas budaya adalah mampu memahami perbandingan serta pemahaman budaya Jepang dan Indonesia. Hal ini akan membuat siswa mengetahui cara bersikap jika berhadapan langsung dengan orang Jepang. Diharapkan siswa juga mampu mengambil nilai-nilai positif dari budaya Jepang tanpa merendahkan budaya Indonesia.

\section{PEMBAHASAN}

Pada observasi pertama, ketiga, keempat dan kelima pembelajaran budaya Jepang diperkenalkan secara teoritikal sedangkan pada observasi kedua pembelajaran dilakukan secara praktikal dengan melakukan praktek budaya. Guru menjelaskan praktek budaya agak sulit dilakukan karena keterbatasan waktu dan tidak semua budaya dapat diaplikasikan dengan melakukan kegiatan. Sehingga guru lebih banyak menjelaskan secara teoritikal tetapi hal ini tidak mengurangi antusias siswa dalam mengikuti pembelajaran dengan materi budaya. Berdasarkan observasi terdapat tiga budaya yang diperkenalkan kepada siswa yaitu letak geografis Jepang yang dikaitkan dengan pakaian tradisional Jepang "yukata", pekerjaan rumah tangga yang dikaitkan dengan pengolahan sampah, dan rumah tradisional Jepang (Minka).

Pada observasi pertama dalam inti pembelajaran guru menyelipkan materi budaya menggunakan metode commenting (mengomentari) yaitu selama pembelajaran di kelas, guru tidak hanya menggunakan buku teks tetapi guru dapat menjelaskan budaya sesuai dengan pengalaman pribadi ( $\mathrm{Li}, 2014)$. Metode commenting digunakan ketika guru 
membahas persamaan dewi Amaterasu dan dewa Surya sebagai dewa matahari. Guru juga menggunakan metode commenting dengan cara meminta komentar atau pendapat siswa terkait letak geografis Jepang. Guru mengaitkan materi tentang letak geografis Jepang dan pakaian tradisional menggunakan metode case study yaitu guru harus membantu siswa mengetahui budaya masyarakat Jepang secara aktif dengan cara yang bervariasi. Tujuannya untuk melatih siswa menjadi seseorang yang modern dan mampu menyesuaikan diri serta mengetahui kondisi Jepang, memiliki pengetahuan cukup tentang masyarakat, politik, ekonomi dan budaya Jepang (Li, 2014). Setelah selesai menjelaskan materi budaya, guru menyampaikan kepada siswa bahwa pada pertemuan selanjutnya akan diadakan praktek memakai yukata.

Pada observasi kedua, guru dan siswa akan praktek menggunakan yukata, tetapi sebelum kegiatan dilakukan guru melanjutkan materi sebelumnya. Sepanjang pelaksanaan praktek terdapat banyak kesalahan yang dialami siswa tetapi mereka tidak mudah menyerah dan sangat bersemangat. Kesalahan yang dilakukan siswa diatasi guru dengan cara menjelaskan kembali dengan lebih mendetail. Guru berkeliling melihat hasil belajar siswa serta membantu jika siswa mengalami kesulitan. Kegiatan ini dilakukan pada akhir pembelajaran menggunakan metode case study (study kasus) yaitu metode umum digunakan dalam pembelajaran bahasa Jepang yang membuat siswa termotivasi untuk belajar secara mandiri tentang budaya Jepang. Contohnya pada praktek memakai yukata, siswa termotivasi untuk memakai yukata secara mandiri.

Guru memberikan penjelasan dan langsung mempraktekan cara menggunakan yukata agar siswa juga dapat langsung mencontoh dan mempraktekannya. Langkah pertama yang harus dilakukan adalah meletakan sisi yukata sebelah kanan dibagian dalam, dan sisi sebelah kiri dibagian luar. Langkah kedua, menyesuaikan panjang yukata pada bagian bawah sesuai dengan tinggi badan agar tidak menyulitkan ketika berjalan. Langkah ketiga, merapikan lipatan kain yukata pada bagian pinggang dan mengikatnya dengan tali rafia. Tali rafia digunakan karena guru tidak memiliki sabuk khusus. Langkah terakhir adalah menutup tali rafia dengan obi dan bentuk menyerupai pita.

Pada observasi ketiga materi budaya yang dijelaskan yaitu tentang pekerjaan rumah tangga yang dilakukan oleh orang Jepang. Hal ini dilakukan pada akhir pembelajaran dengan menggunakan metode commenting untuk mengomentari pekerjaan rumah tangga di Jepang. Guru menjelaskan bahwa di Jepang sangat jarang keluarga memakai jasa asisten rumah tangga, karena harganya yang cukup mahal. Seorang asisten rumah tangga di Jepang biasanya dibayar perjam dengan biaya yang tidak murah. Oleh sebab itu pekerjaan rumah tangga lebih banyak dikerjakan oleh ibu. Kebanyakan wanita Jepang setelah menikah biasanya menjadi ibu rumah tangga. Sehingga semua pekerjaan rumah ibu yang mengerjakan. Tetapi jika sebuah keluarga sudah memiliki anak, anak pun akan dibiasakan mengerjakan pekerjaan rumah sejak dini. Anak diberikan tanggung jawab agar dapat hidup mandiri dikemudian hari. Sedangkan di Indonesia keluarga yang berada dalam ekonomi yang mampu biasanya menggunakan jasa asisten rumah tangga, karena harganya yang relatif terjangkau dan digaji perbulan.

Guru bercerita sambil menyinggung anime Crayon Shinchan yang selalu diminta oleh ibunya untuk pergi berbelanja, menjaga adik, menyiram tanaman dan lain sebagainya. Padahal usia Shinchan baru 5 tahun, tetapi sudah diberikan tanggung jawab untuk mengerjakan pekerjaan rumah. Ibu juga harus memilih pekerjaan rumah yang mampu dikerjakan seorang anak sesuai dengan usia mereka agar tidak terlalu memberatkan bagi anak. Terkadang ibu di Jepang juga membuat jadwal untuk mengerjakan pekerjaan rumah tangga bagi anggota keluarga agar dapat mengerjakannya secara disiplin. Sedangkan di Indonesia ada keluarga yang membuat jadwal pakerjaan rumah tangga dan ada pula pekerjaan rumah tangga yang dilakukan dengan kesadaran sendiri.

Pada observasi keempat guru menjelaskan kembali tentang budaya Jepang berkaitan dengan kebersihan. Di Indonesia sampah hanya dibedakan menjadi dua jenis yaitu organik dan anorganik tetapi di Jepang dibedakan menjadi lebih dari dua jenis sampah. Diantaranya sampah dapat terbakar, sampah tidak dapat dibakar, sampah berukuran besar dan sampah botol/kaleng. Selain itu terdapat pula peraturan-peraturan yang harus dipatuhi seperti kantong sampah dibedakan menjadi beberapa warna sesuai dengan daerahnya. Pengambilan sampah diatur sesuai dengan wilayahnya, biasanya terdapat panduan yang 
menunjukan jadwal hari pengumpulan sampah. Hal ini dilakukan pada akhir pembelajaran dengan menggunakan metode comparing untuk membandingkan tata cara pembuangan sampah di Jepang dan Indonesia. Pada akhir pembelajaran guru juga menggunakan metode intuitivism yaitu pembelajaran budaya menggunakan gambar, video dan media pendukung lain agar siswa lebih mengerti dan dapat melihat langsung budaya Jepang yang sedang dijelaskan (Li, 2014). Dalam kegiatan ini guru menggunakan media powerpoint yang berisi gambar tentang budaya pembuangan sampah di Jepang.

Pada observasi kelima, guru menjelaskan mengenai rumah tradisional Jepang. Rumah tradisional Jepang terdiri dari bahan utama kayu, hal ini bertujuan untuk mengantisipasi bencana gempa serta temperatur yang berubah disetiap musim. Sedangkan rumah tradisional Indonesia dibangun dengan bahan dasar yang berbeda-beda sesuai dengan wilayahnya tetapi umumnya menggunakan batu batako agar bangunan lebih kuat dan kokoh. Guru juga menjelaskan beberapa bagian yang terdapat pada rumah tradisional Jepang diantaranya seperti tatami, genkan, fusuma, dan kamidana. Hal ini dilakukan akhir pembelajaran menggunakan metode comparing yaitu proses membandingkan bahasa ibu dengan bahasa target ( $\mathrm{Li}, 2014)$. Dari observasi pertama, kedua, ketiga, keempat dan kelima menunjukan bahwa pada inti pembelajaran materi budaya yang disampaikan banyak menggunakan metode commenting dan comparing. Pada akhir pembelajaran guru banyak menggunakan metode commenting, comparing, intuitivism, dan case study.

Berdasarkan pemaparan di atas, dapat disimpulkan bahwa metode pembelajaran yang digunakan guru untuk mengimplementasikan pemahaman lintas budaya dalam pembelajaran bahasa Jepang commenting (mengomentari), comparing (perbandingan), intuitivism (intuitivisme), dan case study (study kasus).

Pemahaman budaya yang diberikan guru yaitu budaya letak geografis Jepang dan pakaian tradisional Jepang (yukata), pekerjaan rumah tangga dan pengelolaan sampah, serta rumah tradisional Jepang (Minka).

\section{Simpulan dan Saran}

Berdasarkan hasil penelitian dan pembahasan terkait implementasi pemahaman lintas budaya dalam pembelajaran bahasa Jepang di Kelas XI BB 1 SMA Negeri 4 Singaraja dapat disimpulkan bahwa metode pembelajaran yang digunakan guru untuk mengimplementasikan pemahaman lintas budaya dalam pembelajaran bahasa Jepang adalah commenting (mengomentari), comparing (perbandingan), intuitivism (intuitivisme), dan case study (study kasus).

Guru dan siswa melakukan praktek pengenalan budaya serta mempelajari budaya Jepang secara lebih mendalam. Pengenalan budaya yang diberikan adalah letak geografis dan pakaian tradisional Jepang (yukata), pekerjaan rumah tangga dan penggolahan sampah, serta rumah tradisional Jepang (Minka).

Kendala-kendala yang dialami guru dalam mengimplementasikan pemahaman lintas budaya adalah pada ada inti pembelajaran, dalam mengimplementasikan metode comparing (perbandingan) dan commenting (mengomentari) kendala yang dihadapi guru terkait istilahistilah budaya serta informasi yang sedang dibahas. Tetapi kendala tersebut dapat diatasi guru dengan cara mencari sumber-sumber materi budaya lainnya.Pada akhir pembelajaran, dalam mengimplementasikan metode intuitivism (intuitivisme) kendala yang dihadapi terkait keterbatasan media berupa gambar ilustrasi, video pembelajaran budaya dan alat peraga untuk praktek budaya seperti yukata. Tetapi kendala tersebut dapat diatasi guru dengan cara mencari gambar dan video dari sumber budaya lain dan untuk keterbatasan yukata, guru membentuk kelompok sehingga media dapat dimanfaatkan oleh semua siswa. Selain itu terdapat pula beberapa budaya yang sulit untuk dipraktekan sehingga guru hanya menjelaskan secara teoritikal dan mencari sumber yang lebih mendalam.

Adapun saran yang dapat diberikan dalam penelitian ini adalah sebagai berikut.

(1) Kepada guru bahasa Jepang di SMA Negeri 4 Singaraja agar lebih meningkatkan kreativitas dalam pembelajaran bahasa Jepang khususnya dalam pembelajaran budaya. Guru dapat memvariasikan metode pembelajaran dengan media pembelajaran agar siswa tertarik dan termotivasi dalam pembelajaran bahasa Jepang ataupun budaya Jepang.

(2) Kepada peneliti lain agar dapat memanfaatkan penelitian sejenis sebagai acuan untuk memahami imlementasi pemahaman lintas budaya dalam pembelajaran bahasa Jepang. 


\section{Daftar Pustaka}

Danasasmita, Wawan. 2014. "Guru Bahasa Jepang di Indonesia: Peluang dan Tantangan". Tersedia pada https://www.academia.edu/6127417/Guru Bahasa Jepang di Indonesia Peluang dan Tantangan (diakses 22 Juni 2019)

Taylor. E. B. 2017. Antropologi. Jakarta: Erlangga

Busri, Hasan dkk. 2016. "Pemanfaatan Cross Cultural Understanding (Pemahaman Lintas Budaya) Dalam Bahan Ajar Nusus Adabiyyah (Analisis Teks Sastra)". Tersedia pada https://journal.unnes.ac.id/nju/index.php/JPP/article/viewFile/7663/5345 (diakses tanggal 29 Mei 2019 